\title{
PENYEMPURNAAN FUNGSIONAL ANTI ULTRAVIOLET PADA KAIN POLIESTER MENGGUNAKAN SENG OKSIDA DENGAN METODE IMPREGNASI
}

\author{
ANTI ULTRAVIOLET FUNCTIONAL FINISHING OF POLYESTER FABRIC \\ USING ZINC OXIDE WITH IMPREGNATION METHOD
}

\author{
Doni Sugiyana, Jakariya Nugraha, Agus Surya Mulyawan, Wulan Septiani, Tatang Wahyudi \\ Balai Besar Tekstil, Jalan Jenderal Ahmad Yani No. 390 Bandung \\ E-mail: texirdti@bdg.centrin.net.id
}

Tanggal diterima: 6 Nopember 2019, direvisi: 28 Desember 2019, disetujui terbit: 28 Desember 2019

\begin{abstract}
ABSTRAK
Proteksi terhadap pengaruh negatif radiasi ultraviolet (UV) matahari dapat dicapai melalui aplikasi functional apparel anti UV berbasis kain sintetik poliester. Dalam kegiatan penelitian ini telah dilakukan penyempurnaan kain poliester menggunakan suspensi seng oksida $(\mathrm{ZnO})$ dengan metode impregnasi (padding) untuk memperoleh sifat anti-ultraviolet. Studi ini bertujuan untuk mengembangkan suspensi $\mathrm{ZnO}$ dan metode immobilisasinya pada kain poliester untuk memperoleh performa proteksi UV dan ketahanan yang optimum. Metodologi penelitian meliputi optimasi konsentrasi zat pendispersi polietilen glikol (PEG), ZnO dan binder poliakrilat dalam suspensi yang digunakan dalam proses penyempurnaan kain menggunakan proses pad-dry-cure. Evaluasi dilakukan terhadap diameter partikel $\mathrm{ZnO}$ dalam suspensi, pengaruh konsentrasi $\mathrm{ZnO}$ dan binder pada morfologi kain dan performa anti-UV kain serta ketahanannya. Preparasi suspensi menunjukkan penambahan PEG $0,1 \%$ signifikan menghindari aglomerasi partikel $\mathrm{ZnO}$, sehingga memungkinkan immobilisasi $\mathrm{ZnO}$ hingga konsentrasi 4,0\% tanpa memberi efek perubahan warna pada kain. Penyempurnaan kain poliester menggunakan suspensi $\mathrm{ZnO} 4,0 \%$ dengan konsentrasi binder 5,0\% dan dapat meningkatkan nilai ultraviolet protection factor (UPF) hingga 51,6\% dengan tingkat ketahanan (durability) hingga 10 kali pencucian pada konsentrasi $\mathrm{ZnO} 1,0 \%$.
\end{abstract}

Kata kunci: kain fungsional, poliester, seng oksida, ultraviolet, impregnasi.

\section{ABSTRACT}

Protection against the negative effects of solar ultraviolet (UV) radiation can be obtained through application of functional apparel anti UV based on polyester synthetic fabric. In this research, the finishing of polyester fabric using zinc oxide $(\mathrm{ZnO})$ suspension through impregnation (padding) method to achieve antiultraviolet performance has been carried out. This study aimed to develop the $\mathrm{ZnO}$ suspension and its immobilization method onto polyester fabric in order to obtain optimized UV protection performance dan its durability. The research methodology consists of optimization of the concentration of PEG (polyethylene glycol) dispersing agent, $\mathrm{ZnO}$ and polyacrylate binder in the suspension for fabric finishing using pad-dry-cure processes. Evaluation has been carried out to the diameter of $\mathrm{ZnO}$ particles in suspension, effect of concentration of $\mathrm{ZnO}$ and binder to the fabric morphology, and fabric anti-UV performance as well as its durability. Preparation of suspension shows that additional of PEG 0,1\% significantly prevent the agglomeration of $\mathrm{ZnO}$ particles, therefore immobilization of $\mathrm{ZnO}$ concentration up to $4.0 \%$ became possible without significant color change on fabric. Finishing of polyester fabric using suspension contains $4.0 \% \mathrm{ZnO}$ and $5.0 \%$ binder concentration enhance ultraviolet protection factor (UPF) value up to $51,6 \%$ with durability up to 10 times of washing at $1.0 \% \mathrm{ZnO}$ concentration.

Keywords: functional fabric, polyester, zinc oxide, ultraviolet, mpregnation.

\section{PENDAHULUAN}

Fenomena global penipisan lapisan ozon di atmosfer akibat akumulasi gas-gas tertentu hasil dari aktivitas manusia dalam beberapa dekade terakhir menyebabkan jumlah total radiasi ultraviolet/UV yang mencapai permukaan bumi terus meningkat. ${ }^{1,2}$ Radiasi sinar UV dapat menyebabkan berbagai efek negatif pada manusia terutama berkaitan dengan kesehatan kulit apabila tidak dilindungi. ${ }^{3}$ Proteksi terhadap pengaruh negatif radiasi UV sehari-hari pada umumnya dilakukan melalui penggunaan krim tabir surya 
yang terbukti mampu menetralisir masalah pada kulit secara efektif. Namun demikian, alternatif proteksi yang lebih praktis adalah melalui penggunaan functional apparel dengan kemampuan memproteksi penggunanya dari radiasi UV. Salah satu jenis kain yang menjadi basis pembuatan functional apparel adalah kain sintetik poliester. Kain poliester memiliki beberapa keunggulan antara lain: tahan lama, tidak mudah kusut, lebih cepat kering saat dijemur, lebih tahan terhadap jamur dan bakteri, tahan terhadap pencucian kimia/ dry cleaning dan mudah dalam perawatannya. Selain itu, bahan baku serat poliester memiliki potensi untuk dapat didaur ulang. ${ }^{4}$

Beberapa faktor yang harus dipertimbangkan dalam pembuatan kain fungsional anti-UV adalah efektivitas proteksi anti-UV, kenyamanan pengguna pakaian dan ketahanan (durability) material tekstil. Sifat anti-UV pada kain dapat diperoleh melalui proses fungsionalisasi kain sehingga mampu mengabsorpsi radiasi UV dengan efektif.. ${ }^{5}$ Bahan aktif yang digunakan adalah material yang memiliki kemampuan daya serap (absorpsi) UV yang optimum. Senyawa seng oksida $(\mathrm{ZnO})$ adalah salah satu absorber anorganik yang paling banyak digunakan dalam upaya proteksi radiasi UV., Senyawa $\mathrm{ZnO}$ memiliki keunggulan karena memiliki karakteristik spektrum absorpsi UV yang lebar, dibandingkan senyawa lain yang memiliki puncak absorpsi hanya pada panjang gelombang tertentu. ${ }^{\mathbf{8}, 9,10}$ Metode penyempurnaan yang sesuai pada permukaan kain dapat dilakukan dengan mengaplikasikan beberapa cara diantaranya: spinning, coating, dan padding. ${ }^{11,12,13}$.

Pengembangan kain fungsional anti-UV telah dilakukan pada studi penulis sebelumnya menggunakan kain kapas dengan metode padding, ${ }^{14,15}$ namun masih memerlukan penelitian lanjutan untuk aplikasi pada kain sandang. Preparasi suspensi $\mathrm{ZnO}$ dengan distribusi partikel $\mathrm{ZnO}$ yang seragam pada kain merupakan salah satu upaya awal untuk memperoleh performa anti-UV yang optimum. Penggunaan zat pendispersi, binder dan $\mathrm{ZnO}$ pada konsentrasi optimum dengan aplikasi proses pad-dry-cure diperkirakan akan dapat meningkatkan ketahanan pada kain dan proteksi UV yang maksimum. Dalam penelitian ini dipelajari metode preparasi suspensi $\mathrm{ZnO}$ dan immobilisasinya pada kain sandang berbahan poliester dengan metode impregnasi untuk memperoleh performa anti UV.

\section{METODE}

\section{Bahan dan peralatan penelitian}

Bahan yang digunakan dalam penelitian ini antara lain: kain poliester (gramasi 126,6 gram $/ \mathrm{m}^{2}$ ) yang telah diproses dyeing-finishing (PT Trisulatex), seng oksida (Nano Center Indonesia), binder poliakrilat (Rudolph), zat pendispersi polietilen glikol/PEG (Merck) dan air demineralisasi (Brataco). Peralatan yang digunakan antara lain: mesin pad-dry-cure (Werner Mathis $A G)$, pengaduk magnetik, sonikator dan oven.

\section{Preparasi suspensi ZnO}

Percobaan optimasi zat pendispersi dilakukan menggunakan suspensi dengan komposisi konsentrasi ZnO 2,0\% dan PEG (0; 0,05; $0,1 ; \quad 0,5 ; \quad 1,0 ; \quad 2,0) \%$ dalam $100 \mathrm{~mL}$ air demineralisasi tanpa menggunakan binder. Suspensi $\mathrm{ZnO}$ kemudian disonikasi selama 30 menit. Evaluasi dilakukan melalui pengukuran diameter rata-rata partikel $\mathrm{ZnO}$ dan distribusinya dalam suspensi menggunakan particle size analyzer (PSA).

\section{Variasi konsentrasi ZnO dan binder dalam suspensi}

Percobaan optimasi konsentrasi $\mathrm{ZnO}$ dilakukan menggunakan suspensi $(1000 \mathrm{~mL})$ dengan komposisi: $\mathrm{ZnO}(0,0-1,0-2,0-3,0-4,0)$ $\%$, poliakrilat $(5 \%)$ dan PEG (konsentrasi optimum). Percobaan optimasi konsentrasi binder dilakukan menggunakan suspensi $(1000 \mathrm{~mL})$ dengan komposisi: poliakrilat $(0,0-3,0-5,0-8,0)$ $\%$, $\mathrm{ZnO}(1,0 \%)$ dan PEG (konsentrasi optimum). Suspensi dengan variasi konsentrasi $\mathrm{ZnO}$ dan binder diimmobilisasikan pada kain poliester dengan proses pad-dry-cure.

\section{Proses pad-dry-cure}

Sampel kain poliester disiapkan dengan ukuran $40 \mathrm{~cm} \times 32 \mathrm{~cm}$. Penyempurnaan sampel kain diawali dengan proses impregnasi, yaitu proses perendaman ke dalam larutan suspensi $\mathrm{ZnO}$ sebanyak 3 kali dan diperas hingga wpu (wet pickup) $80 \%$. Kain selanjutnya melalui proses pengeringan (drying) pada temperatur $110^{\circ} \mathrm{C}$ selama 5 menit. Proses dilanjutkan dengan tahap pemanasawetan (curing) pada temperatur $150^{\circ} \mathrm{C}$ selama 3 menit. Setelah proses pad-dry-cure, kain dibiarkan pada temperatur ruang selama 24 jam, dilanjutkan dengan sonikasi selama 10 menit untuk melepaskan partikel $\mathrm{ZnO}$ yang tidak menempel pada kain.

\section{Pengujian dan karakterisasi}

Ukuran diameter partikel $\mathrm{ZnO}$ dianalisis dengan menggunakan instrumen particle size analyzer/PSA (Beckman Coulter tipe LS 13 320). Karakteristik dan morfologi kain anti UV dievaluasi menggunakan instrumen scanning electron microscopy/SEM (JEOL, JSM 6510) dan X-ray Diffraction/XRD (PANalytical X'Pert PRO, PW3040/x0 X'Pert PRO, Netherland). Uji beda warna dilakukan sesuai standar cara uji SNI-ISO 105-J03 2010. Sifat anti ultraviolet kain dievaluasi ketahanannya terhadap pencucian berulang sesuai 

dkk.)

standar cara uji pada SNI ISO 105-C06-2010. Evaluasi sifat proteksi UV sampel kain hasil percobaan dilakukan melalui pengujian ultraviolet protection factor (UPF) menggunakan instrumen spektrofotometer UPF (JASCO, V-750), mengikuti standar cara uji pada AS/NZS 4399: 2017.

\section{HASIL DAN PEMBAHASAN}

\section{Preparasi suspensi $\mathrm{ZnO}$}

Pembuatan suspensi $\mathrm{ZnO}$ menggunakan zat pendispersi bertujuan untuk menghindari terjadinya aglomerasi partikel sehingga diperoleh suspensi dengan ukuran partikel berukuran sub-mikrometer dan stabil. Penggunaan zat pendispersi polietilena glikol (PEG) telah dilakukan dengan variasi konsentrasi (\%): $0 ; 0,05 ; 0,1 ; 0,5 ; 1,0 ; 2,0$. Hasil pengujian PSA pada seluruh sampel hasil percobaan menunjukkan bahwa penggunaan PEG optimum diperoleh pada konsentrasi $0,1 \%$ dengan diameter rata-rata partikel dalam suspensi sebesar $285 \mathrm{~nm}$.
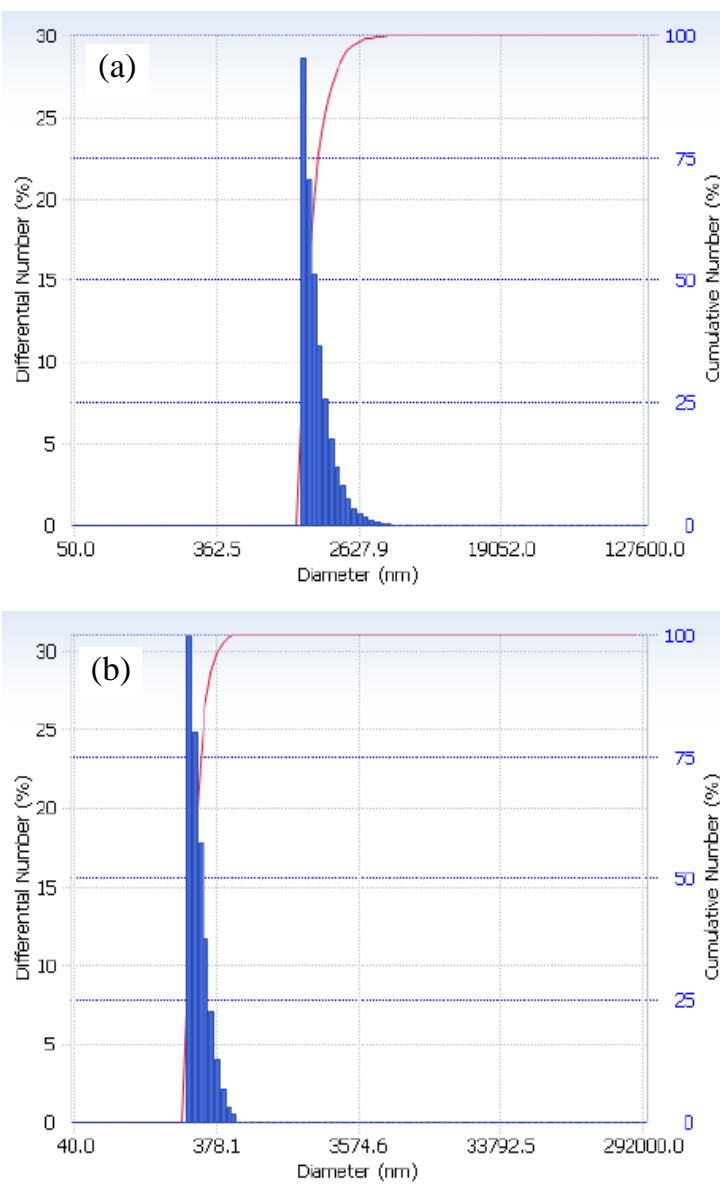

Gambar 1. Hasil pengujian PSA pada suspensi $\mathrm{ZnO}$ : a) blanko tanpa zat pendispersi; b) dengan penambahan zat pendispersi $0,1 \%$.

Hasil pengujian PSA berupa distribusi diameter partikel $\mathrm{ZnO}$ pada sampel suspensi sebelum dan sesudah penambahan zat pendispersi optimum ditunjukkan pada Gambar 1. Sebelum penambahan zat pendispersi, diameter rata-rata partikel $\mathrm{ZnO}$ adalah sebesar 1456,1 nm, sedangkan setelah penambahan zat pendispersi diameter ratarata partikel $\mathrm{ZnO}$ menurun menjadi 285,9 $\mathrm{nm}$. Sebelum penambahan PEG, ukuran partikel yang cukup besar dipengaruhi oleh aglomerasi antar partikel $\mathrm{ZnO}$ yang kemudian berhasil dikurangi seiring penambahan PEG pada konsentrasi optimum.

Pengujian PSA lebih lanjut terhadap seluruh suspensi hasil percobaan menunjukkan hubungan antara diameter rata-rata partikel $\mathrm{ZnO}$ dengan variasi konsentrasi PEG seperti ditunjukkan pada Gambar 2. Grafik pada Gambar 2 memperlihatkan bahwa penambahan PEG hingga konsentrasi 0,1\% mampu memperkecil diameter rata-rata partikel dari 1,46 mikrometer hingga 286 nanometer. Penambahan konsentrasi PEG lebih lanjut ternyata tidak dapat menurunkan diameter partikel, bahkan menambah ukuran partikel. Hasil percobaan ini mengindikasikan bahwa PEG hingga konsentrasi $0,1 \%$ mampu menambah kestabilan partikel dalam fluida dan menghambat terjadinya aglomerasi partikel. Molekul PEG yang menempel di permukaan partikel $\mathrm{ZnO}$ memperbesar gaya tolak antar partikel sehingga partikel terdispersi dengan baik selanjutnya mengurangi kecenderungan pengendapan. Penambahan PEG lebih lanjut dengan konsentrasi yang lebih tinggi dari $0,1 \%$ sebaliknya akan menurunkan kestabilan partikel. Lapisan PEG yang terlalu tebal pada permukaan $\mathrm{ZnO}$ dapat mengakibatkan partikel menjadi lebih berat dan meningkatkan kecenderungan pengendapan.

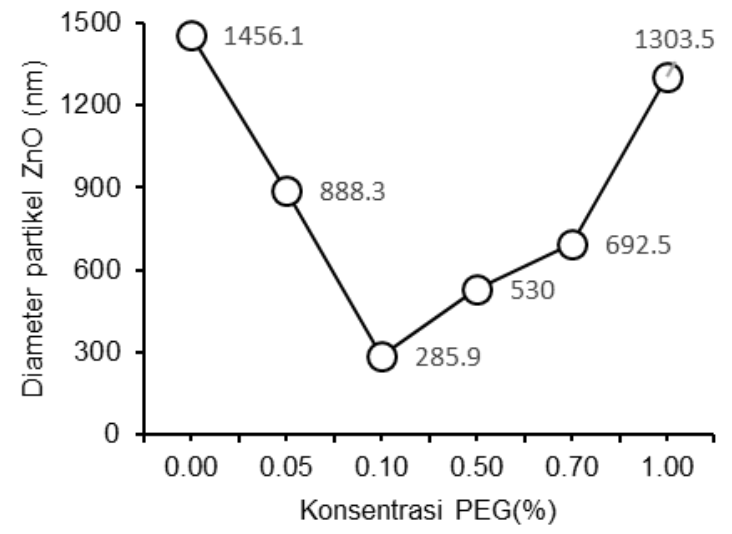

Gambar 2. Grafik pengaruh konsentrasi PEG (\%) terhadap diameter partikel $\mathrm{ZnO}$ dalam suspensi.

\section{Variasi konsentrasi ZnO dalam suspensi}

Percobaan penyempurnaan kain poliester menggunakan suspensi pada rentang konsentrasi $\mathrm{ZnO}(1,0 \%-4,0 \%)$ dengan proses pad-dry-cure dilakukan dengan tujuan untuk mengevaluasi 
karakter distribusi partikel $\mathrm{ZnO}$ pada kain. Evaluasi pada sampel kain dilakukan melalui pengambilan citra SEM dan uji beda warna. Hasil pengamatan citra SEM sampel kain hasil percobaan pada Gambar 3 memperlihatkan adanya peningkatan distribusi partikel $\mathrm{ZnO}$ pada permukaan serat kain seiring peningkatan konsentrasi $\mathrm{ZnO}$ dalam suspensi.

Citra SEM pada Gambar 3 menunjukkan bahwa immobilisasi partikel $\mathrm{ZnO}$ terdistribusi cukup merata pada permukaan serat meskipun

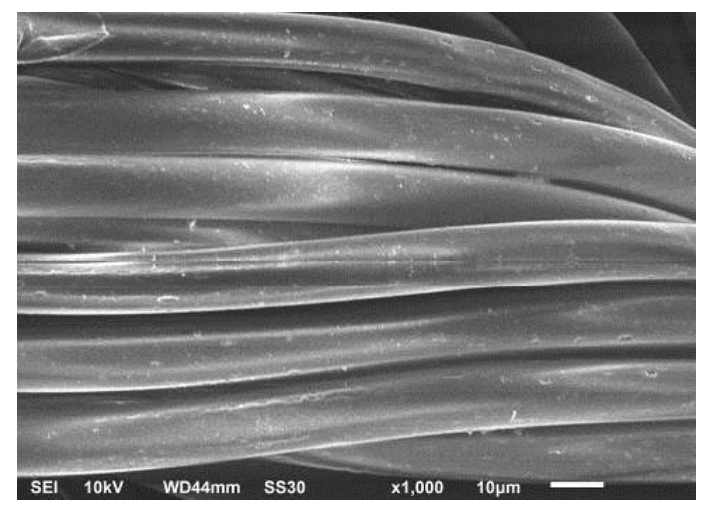

(a)

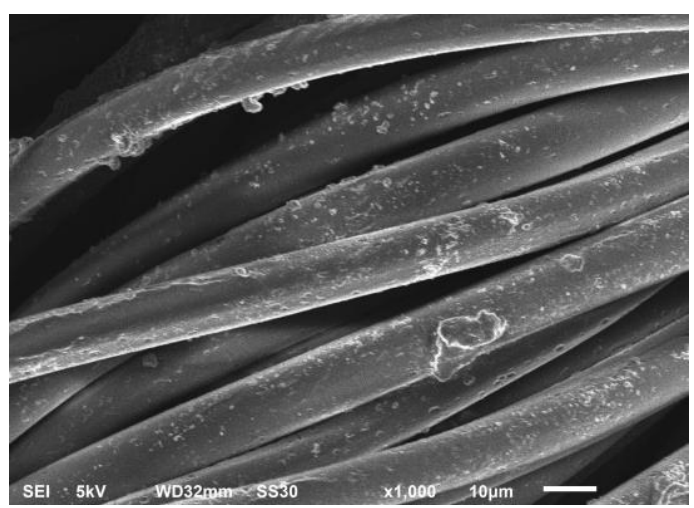

(c) terdapat aglomerasi partikel pada beberapa bagian. Peningkatan konsentrasi $\mathrm{ZnO}$ dari $1,0 \%$ hingga 4,0\% menunjukkan bahwa meskipun partikel $\mathrm{ZnO}$ tampak semakin padat, namun distribusinya pada kain masih relatif homogen. Selain pengamatan mikroskopik dengan SEM, penampakan visual sampel kain pada Gambar 4 menunjukkan tidak ditemukan bercak/gumpalan putih pada permukaan kain yang dapat menjadi indikator terjadinya aglomerasi partikel $\mathrm{ZnO}$.

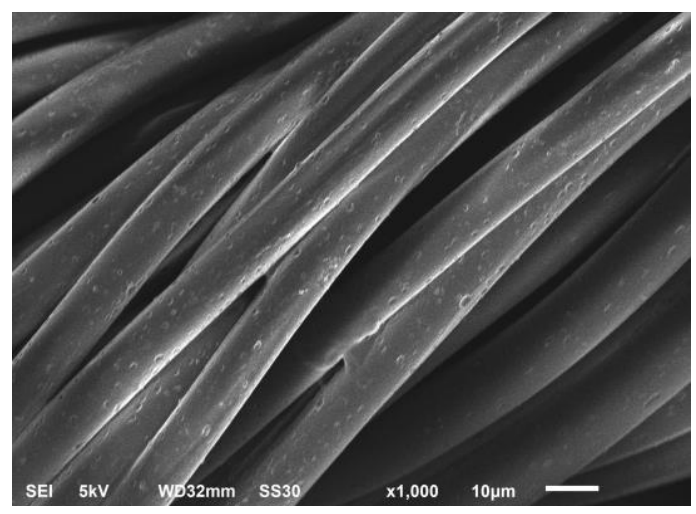

(b)

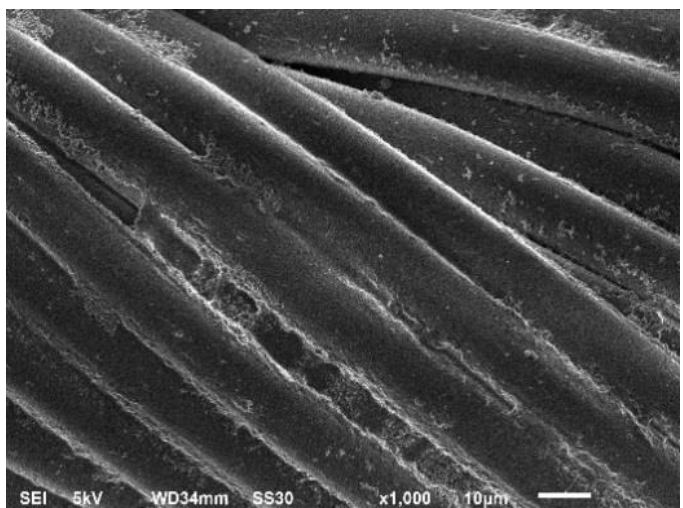

(d)

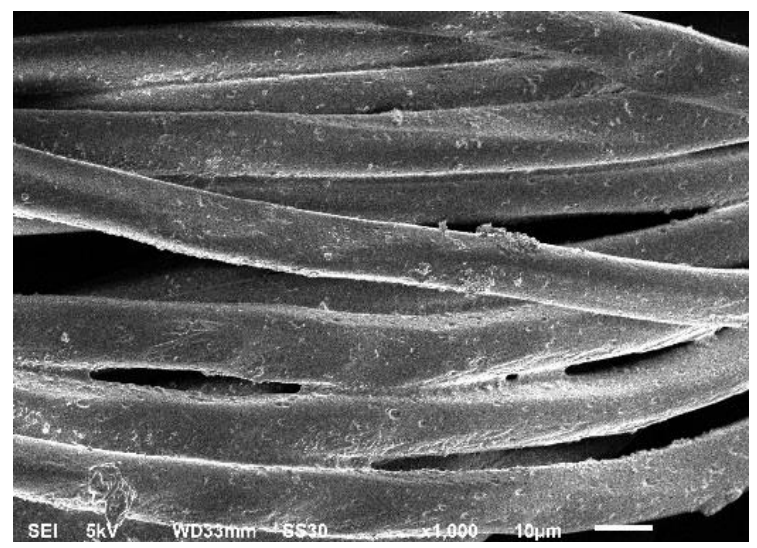

(e)

Gambar 3. Citra SEM sampel kain pada percobaan variasi konsentrasi ZnO: a) blanko; b) 1,0\%; c) 2,0\%; d) $3,0 \%$; e) 4,0\%. (Perbesaran 1000x). 

dkk.)

Setelah pengamatan secara visual dan pengamatan mikroskopik, konfirmasi lebih lanjut dilakukan melalui uji beda warna pada semua sampel kain, baik kain blanko maupun kain yang terimmobilisasi $\mathrm{ZnO}$. Tabel 1 menampilkan nilai hasil pengujian perbedaan warna. Perbedaan kecerahan/lightness $(\Delta \mathrm{L})$, immobilisasi $\mathrm{ZnO}$ pada kain menghasilkan kain dengan kecenderungan lebih gelap daripada kain tanpa penambahan $\mathrm{ZnO}$. Pada semua sampel yang terimmobilisasi $\mathrm{ZnO}$, perbedaan arah warna $(\Delta \mathrm{a})$ menunjukkan kecenderungan lebih merah, sedangkan perbedaan arah warna $(\Delta \mathrm{b})$ menghasilkan kain yang lebih kuning dibandingkan sampel blanko. Nilai perbedaan warna $(\Delta \mathrm{E})$ pada seluruh sampel kain pada rentang konsentrasi $\mathrm{ZnO} 1,0 \%$ - 4,0\%, menunjukkan perbedaan warna kurang dari skala 1 , mengindikasikan beda warna yang terjadi tidak signifikan dan masih dapat diterima.

Penampakan visual dan hasil uji beda warna yang cukup baik pada sampel terimmobilisasi $\mathrm{ZnO}$ hingga 4,0\% dimungkinkan karena ukuran partikel $\mathrm{ZnO}$ yang melekat pada permukaan kain berada pada rentang $100-300 \mathrm{~nm}$ (Gambar 5). Hal ini memungkinkan distribusi yang cukup uniform pada permukaan kain sehingga tidak menimbulkan perbedaan yang signifikan dibandingkan dengan sampel kain blanko. Penambahan zat pendispersi juga membantu agar tidak terjadi aglomerasi berupa gumpalan yang menempel pada permukaan kain.

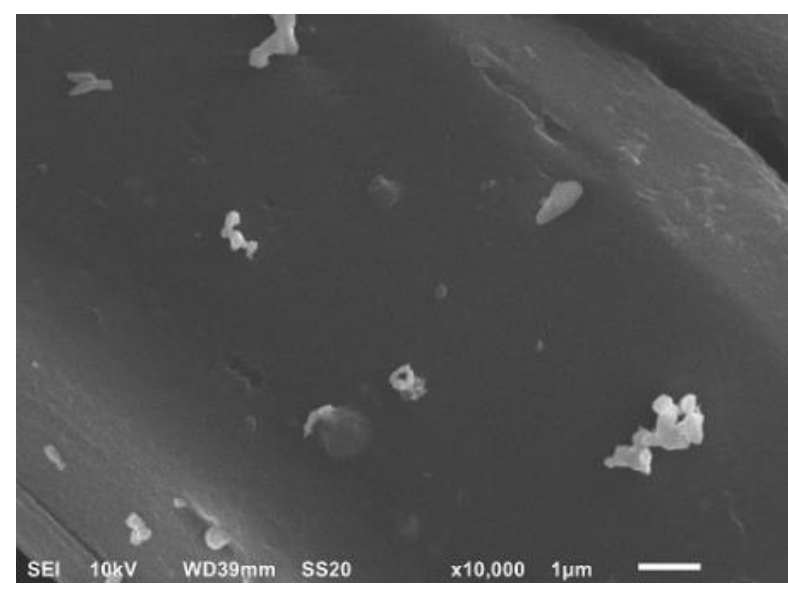

Gambar 5. Citra SEM partikel ZnO terimmobilisasi pada permukaan kain (perbesaran 10.000x).

Tabel 1. Hasil uji beda warna sampel kain variasi konsentrasi $\mathrm{ZnO}$

\begin{tabular}{llllll}
\hline No & Sampel kain & $(\boldsymbol{\Delta L})$ & $(\boldsymbol{\Delta} \mathbf{a})$ & $(\boldsymbol{\Delta b})$ & $(\boldsymbol{\Delta E})$ \\
\hline 1 & ZnO 1.0\% & -0.39 & 0.04 & 0.21 & 0.45 \\
2 & ZnO 2.0\% & -0.38 & 0.08 & 0.46 & 0.55 \\
3 & ZnO 3.0\% & -0.31 & 0.06 & 0.43 & 0.60 \\
4 & ZnO 4.0\% & -0.38 & 0.03 & 0.41 & 0.97 \\
\hline
\end{tabular}

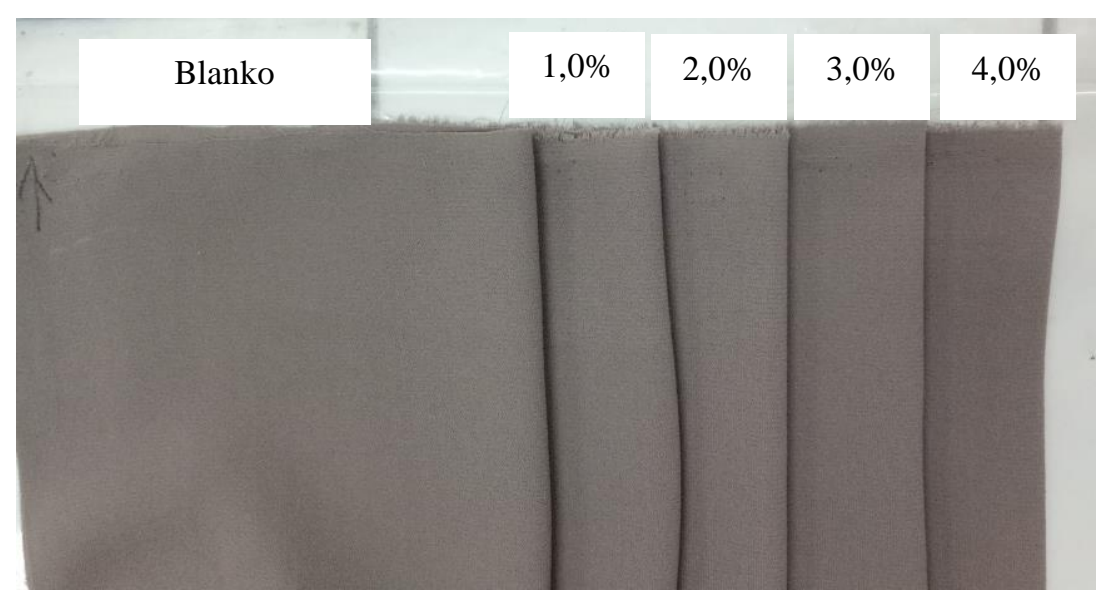

Gambar 4. Hasil uji beda warna pada percobaan variasi konsentrasi $\mathrm{ZnO}$

Aplikasi ukuran partikel yang cukup kecil (<300 nm) memiliki berbagai keuntungan seperti luas permukaan spesifik yang besar, sifat absorpsi UV yang optimum, aktivitas permukaan yang besar, performa transfer panas yang baik dan sifat suspensi cair yang stabil. ${ }^{\mathbf{1 6}, 17}$ Nanopartikel $\mathrm{ZnO}$ dapat menunjukkan sifat proteksi UV yang lebih baik dari mikropartikel, namun beberapa referensi 
menyebutkan nanopartikel $\mathrm{ZnO}$ komersial umumnya cenderung mudah teraglomerasi sehingga sulit terdispersi dengan seragam pada media kain dan memiliki ketahanan kurang baik. $^{\mathbf{3 , 4}}$ Upaya stabilisasi suspensi dan metode immobilisasi pada penelitian ini memiliki tujuan utama untuk mengurangi semaksimal mungkin kemungkinan aglomerasi partikel pada permukaan kain.

\section{Variasi konsentrasi binder dalam suspensi}

Percobaan penyempurnaan kain poliester menggunakan suspensi $\mathrm{ZnO}$ mengandung binder pada beberapa nilai konsentrasi $(3,0-5,0-8,0) \%$ dengan proses pad-dry-cure bertujuan untuk mengevaluasi karakteristik dan morfologi permukaan kain setelah melalui proses penyempurnaan. Citra SEM hasil percobaan variasi konsentrasi binder $(3 \%, 5 \%$ dan $8 \%)$ pada sampel kain diperlihatkan pada Gambar 6. Citra SEM menunjukkan bahwa penambahan konsentrasi binder dalam suspensi menyebabkan terjadinya peningkatan ketebalan lapisan binder pada permukaan kain yang dapat mempengaruhi tekstur dan pegangan kain. Dalam penelitian ini tidak

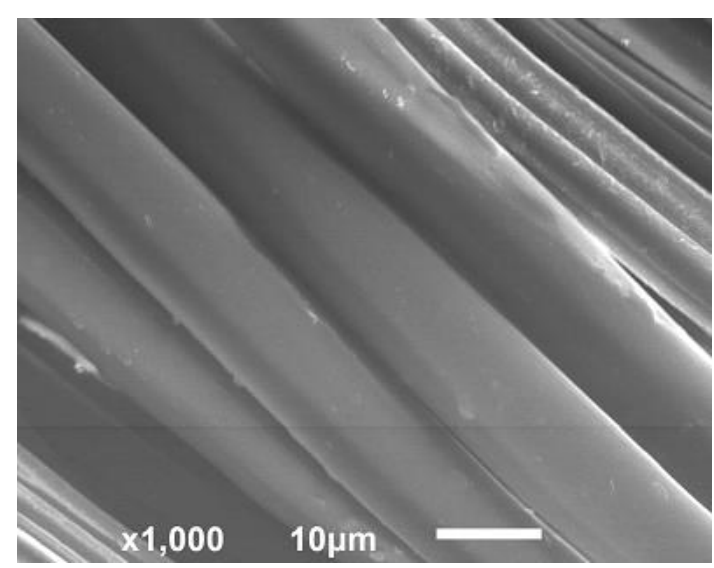

(a)

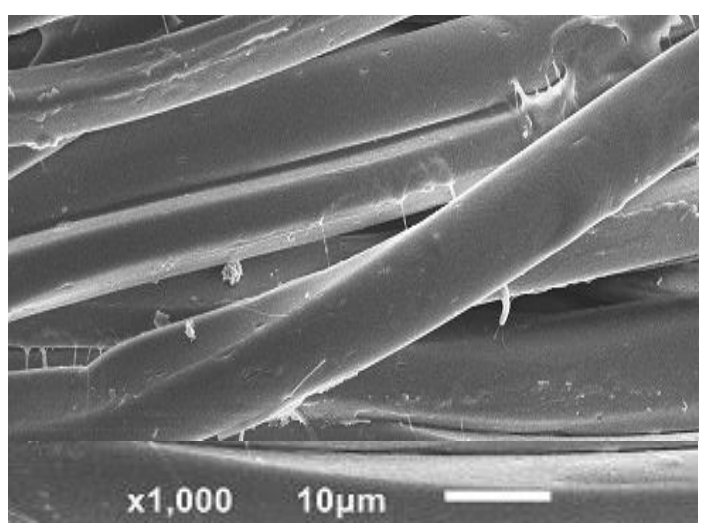

(c) dilakukan pengujian kekakuan kain dengan pengaruh konsentrasi binder, sehingga tidak dapat menampilkan data kuantitatif terkait konsentrasi binder paling optimum. Namun demikian konsentrasi binder 5\% secara kualitatif menghasilkan pegangan cukup baik dan digunakan dalam percobaan selanjutnya.

Citra SEM seperti ditunjukkan pada Gambar 6 memperlihatkan juga bahwa lapisan binder pada permukaan kain menjadi media perlekatan partikel $\mathrm{ZnO}$ pada lapisan binder tersebut. Semakin bertambahnya ketebalan binder dapat mengimmobilisasi konsentrasi $\mathrm{ZnO}$ yang lebih tinggi. Lapisan binder yang lebih tebal juga memungkinkan perlekatan $\mathrm{ZnO}$ pada permukaan kain menjadi semakin baik. Namun demkian, lapisan binder yang terlalu tebal akan menyebabkan kain menjadi kaku sehingga tidak sesuai untuk aplikasi kain apparel. Sebaliknya, lapisan binder yang tipis memungkinkan pegangan kain menjadi lentur, namun akan menyebabkan ketahanan perlekatan $\mathrm{ZnO}$ menjadi kurang baik.

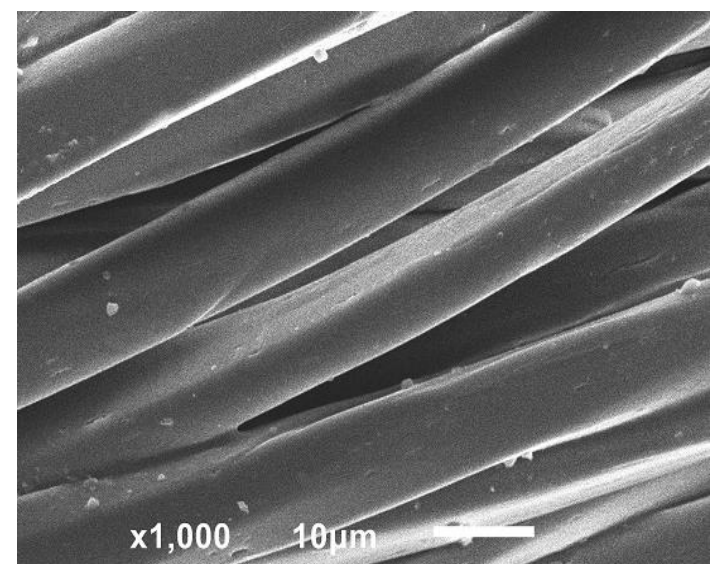

(b)

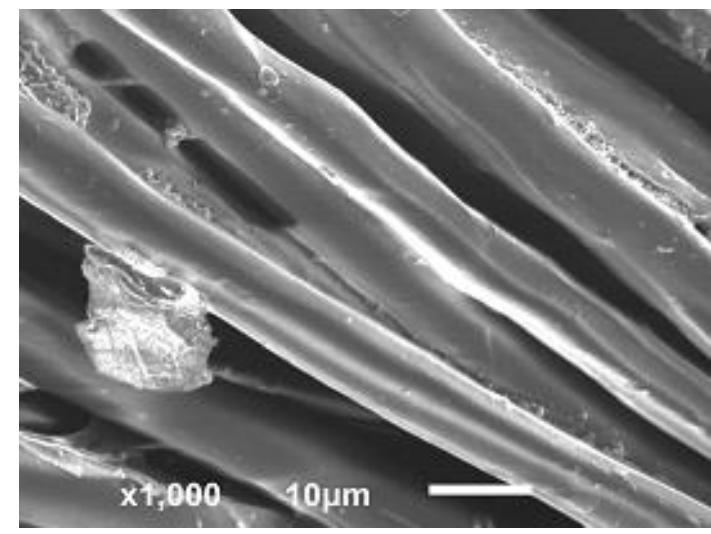

(d)

Gambar 6. Citra SEM kain terimmobilisasi ZnO dengan variasi konsentrasi binder: a) blanko; b) 3\%; c) 5\%; d) $8 \%$ (Perbesaran 1000x) 

dkk.)

Pada konsentrasi binder optimum, ketahanan proteksi anti-UV yang diperoleh pada kain selain dihasilkan oleh tingkat perlekatan yang lebih baik, juga disebabkan terperangkapnya partikel $\mathrm{ZnO}$ dalam senyawa binder yang berikatan dengan serat kain. Berdasarkan hasil yang diperoleh, konsentrasi binder poliakrilat 5\% merupakan nilai yang cukup optimum. Diharapkan, penggunaan konsentrasi binder yang tepat memungkinkan terjadinya perlekatan partikel yang kuat pada matriks kain yang akan dievaluasi lebih lanjut melalui uji tahan cuci.

\section{Evaluasi performa dan ketahanan proteksi anti- UV}

Evaluasi terhadap hasil proses penyempurnaan kain dalam penelitian ini adalah dengan menguji respon kain terhadap pengaruh radiasi UV melalui pengukuran nilai UPF. Pengukuran nilai UPF dilakukan pada sampel kain blanko, sampel kain yang mengandung binder dan sampel kain yang mengandung binder dan $\mathrm{ZnO}$. Hasil uji UPF pada sampel kain ditunjukkan pada Tabel 2.

Tabel 2. Hasil uji UPF sampel kain

\begin{tabular}{clc}
\hline No & \multicolumn{1}{c}{ Sampel kain } & Nilai UPF \\
\hline 1 & Kain blanko & 18,2 \\
2 & Kain + binder & 18,9 \\
3 & Kain + binder + ZnO 1\% & 23,8 \\
4 & Kain + binder + ZnO 2\% & 25,1 \\
5 & Kain + binder + ZnO 3\% & 26,1 \\
6 & Kain + binder + ZnO 4\% & 27,6 \\
\hline
\end{tabular}

Berdasarkan hasil pada Tabel 2 dapat dilihat bahwa penambahan $\mathrm{ZnO}$ berpengaruh signifikan pada nilai UPF. Penambahan binder pada blanko sampel kain berkontribusi pada peningkatan nilai UPF hanya sebesar $3.7 \%$, sedangkan penambahan $\mathrm{ZnO} 1 \%$ pada blanko kain dengan bantuan binder mampu meningkatkan nilai UPF hingga $23.5 \%$. Peningkatan konsentrasi $\mathrm{ZnO}$ lebih lanjut hingga 4\% mampu meningkatkan nilai UPF hingga 51.6\%. Hasil uji UPF pada sampel kain poliester mengindikasikan bahwa penambahan $\mathrm{ZnO}$ sebagai agen aktif anti-UV berpengaruh signifikan pada peningkatan kemampuan material kain dalam memproteksi kain dari radiasi UV. Hasil penelitian ini menggambarkan kemampuan $\mathrm{ZnO}$ dalam memproteksi kain melalui mekanisme absorpsi radiasi sinar UV.

Partikel ZnO sebagai absorber UV berperan dalam memproteksi kain terhadap radiasi UV melalui beberapa skema antara lain menghilangkan intensitas UV dan atenuasi sinar UV. ${ }^{6}$ Penghilangan intensitas radiasi UV terjadi melalui konversi energi cahaya menjadi bentuk lain seperti panas melalui proses eksitasi elektron dari pita valensi ke pita konduksi. Atenuasi radiasi UV dapat terjadi melalui absorpsi band gap dan penyebaran (scattering) sinar UV. ${ }^{18}$ Proteksi UV dengan penggunaan nanopartikel $\mathrm{ZnO}$ akan optimum apabila terimmobilisasi pada permukaan kain dengan seragam tanpa mengalami aglomerasi. Salah satu kelebihan partikel $\mathrm{ZnO}$ adalah memiliki distribusi ukuran partikel yang lebih sempit (20-40 nm) dibanding senyawa oksida lain sehingga memungkinkan distribusi lebih seragam. ${ }^{\mathbf{1 9 , 2 0}}$

Evaluasi terhadap ketahanan proteksi antiUV melalui uji UPF dilakukan pada sampel kain yang telah dicuci rumah tangga secara berulang. Percobaan ini pada dasarnya untuk mengevaluasi ketahanan perlekatan partikel $\mathrm{ZnO}$ melalui uji tahan cuci terhadap sampel kain terimmobilisasi $\mathrm{ZnO} 1 \%$ hingga 20 kali pencucian rumah tangga. Hasil pengujian UPF terhadap sampel dengan pengaruh pencucian rumah tangga ditunjukkan pada Tabel 3.

Hasil pada Tabel 3 memperlihatkan bahwa proses pencucian rumah tangga berpotensi meluruhkan perlekatan $\mathrm{ZnO}$ dan mengurangi konsentrasi $\mathrm{ZnO}$ pada kain sehingga dapat menurunkan nilai UPF. Pencucian rumah tangga hingga 10 kali pencucian pada kain poliester $(\mathrm{ZnO}$ $1 \%$ dan binder 5\%) masih mempertahankan nilai UPF hingga 23,2. Pencucian lebih lanjut hingga 15 kali cuci menurunkan nilai UPF hingga 21,2. Nilai UPF pada sampel kain poliester setelah 20 kali pencucian hampir mendekati nilai UPF sebelum penambahan $\mathrm{ZnO}$.

Grafik uji XRD terhadap sampel kain dengan 10 kali pencucian (Gambar 7) menunjukkan puncak 5.08358; 3.51361; 2.47830; 1.47555; 1.31104; $1.22645 \AA$, yang mengidentifikasi keberadaan senyawa oksida $\mathrm{ZnO}$. Keberadaan puncak pada hasil uji XRD ini hampir identik dengan sampel kain terimmobilisasi $\mathrm{ZnO}$ sebelum pencucian. Perlakuan pencucian lebih jauh pada sampel kain dengan 15 kali pencucian menunjukkan konsentrasi 
$\mathrm{ZnO}$ yang terimmobilisasi pada kain sudah tidak dapat teridentifikasi dengan jelas oleh uji XRD.

Evaluasi nilai UPF dan hasil uji XRD terhadap sampel setelah pencucian rumah tangga hingga 20 kali menggambarkan bahwa ketahanan proteksi UV kain hasil penyempurnaan dalam penelitian ini masih harus ditingkatkan. Jenis dan konsentrasi binder sangat berpengaruh pada perlekatan partikel $\mathrm{ZnO}$ pada permukaan kain. Faktor lain adalah kondisi proses penyempurnaan seperti $\mathrm{pH}$ dan temperatur merupakan variabel yang harus dipelajari dalam penelitian lanjutan.

Tabel 3. Hasil uji UPF sampel kain

\begin{tabular}{clc}
\hline No & Sampel kain & Nilai UPF \\
\hline 1 & Kain blanko & 18,2 \\
2 & Kain + binder & 18,9 \\
3 & Kain + binder + ZnO & 23,8 \\
4 & Kain + binder + ZnO (cuci 5x) & 23,6 \\
5 & Kain + binder + ZnO (cuci 10x) & 23,2 \\
6 & Kain + binder + ZnO (cuci 15x) & 21,2 \\
7 & Kain + binder + ZnO (cuci 20x) & 19,1 \\
\hline
\end{tabular}

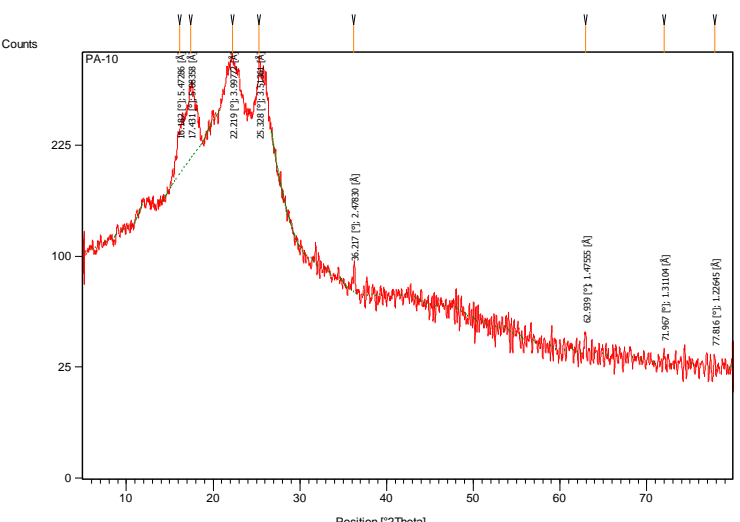

(a)

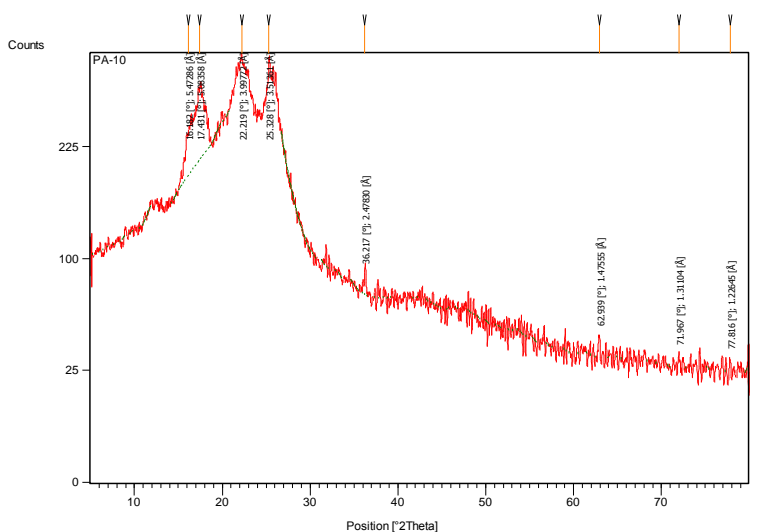

(b)

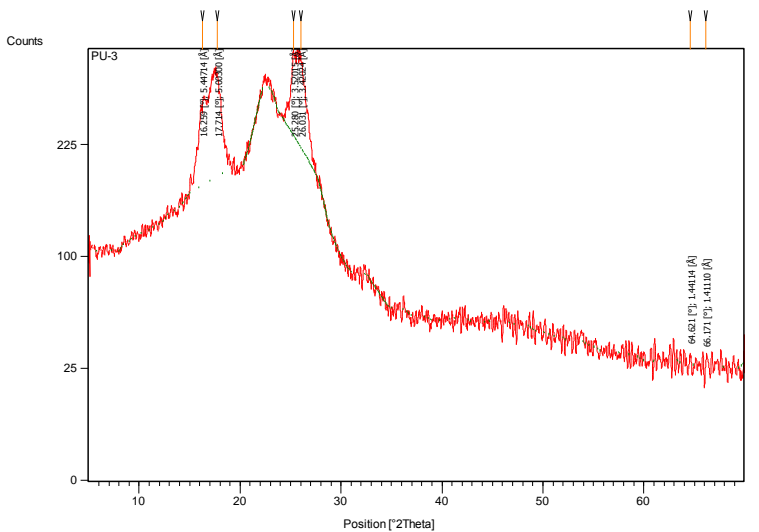

(c)

Gambar 7. Hasil uji XRD kain terimmobilisasi ZnO dengan pengaruh pencucian: a) sebelum pencucian; b) 10 kali pencucian; c) 15 kali pencucian. 

dkk.)

\section{KESIMPULAN}

Penyempurnaan kain poliester untuk memperoleh kain fungsional anti-UV menggunakan suspensi $\mathrm{ZnO}$ dengan metode impregnasi (padding) telah berhasil dilakukan. Suspensi $\mathrm{ZnO}$ yang stabil diperoleh dengan penggunaan zat pendispersi PEG $0,1 \%$. Perlekatan partikel $\mathrm{ZnO}$ pada kain semakin baik seiring peningkatan penggunaan konsentrasi binder, penggunaan konsentrasi binder poliakrilat optimum pada $5 \%$. Penggunaan konsentrasi $\mathrm{ZnO}$ hingga $4,0 \%$ pada kain menghasilkan beda warna yang masih dapat diterima, dengan peningkatan nilai UPF sebesar 51,6\% hingga mencapai nilai UPF 27,6. Proteksi anti-UV kain fungsional yang diperoleh dalam penelitian ini mencapai ketahanan terhadap pencucian rumah tangga hingga 10 kali pencucian pada konsentrasi $\mathrm{ZnO} 1,0 \%$.

\section{UCAPAN TERIMAKASIH}

Penelitian ini terlaksana dengan bantuan anggaran penelitian DIPA Balai Besar Tekstil tahun 2018.

\section{PUSTAKA}

1. WHO, Solar ultraviolet radiation: global burden of disease from solar ultraviolet radiation, Environmental burden of disease series 13 (2006).

2. Dutra, E.A., Oliveira, D.A., Hackmann, E.R., \& Santoro. M.I. Determination of sun protection factor (SPF) of sunscreens by ultraviolet spectrophotometry. Brazilian Journal of Pharmaceutical Sciences 40 (3), 381 -385 (2004).

3. Kim, Y.K. Ultraviolet protection finishes for textiles. Functional finishes for textile. $1^{\text {st }}$ ed. Elsevier (2015)

4. Radetic, M. Review: Functionalization of textile materials with $\mathrm{TiO}_{2}$ nanoparticles. Journal of Photochemistry and Photobiology C: Photochemistry Reviews 16, 62- 76 (2013).

5. Li, H., Deng H. \& Zhao, J. Performance research of polyester fabric treated by nano titanium dioxide (nano- $\mathrm{TiO}_{2}$ ) anti-ultraviolet finishing. International Journal of Chemistry 1(1), 57 - 62 (2009).

6. Saravanan, D. Ultraviolet protection textile materials. AUTEX Research Journal 7 (1), 53 62 (2007).

7. Selishchev, D.S., Karaseva, I.P., Uvaev, V.V. Kozlov, D.V., \& Parmon, V.N. Effect of preparation method of functionalized textile materials on their photocatalytic activity and stability under UV irradiation. Chemical Engineering Journal 224, 114-120 (2013).
8. El-Hady, M.M., Farouk, A. dan Sharaf, S. Flame retardancy and UV protection of cotton based fabrics using nano $\mathrm{ZnO}$ and polycarboxylic acids, Carbohydrate Polymers 92, 400- 406 (2013).

9. Zayat, M., Garcia-Parejo, P. \& Levy, D. Preventing UV-light damage on light sensitive materials using a highly protective UVabsorbing coating, Chemical Society Reviews 36, 1270 - 1281 (2007).

10. Sawaji, J. \& Yoshikawa, T. Quantitative evaluation of antifungal activity of metallic oxide powders $(\mathrm{MgO}, \mathrm{CaO}$ and $\mathrm{ZnO})$ by an indirect conductimetric assay. Journal of Applied Microbiology 96 (4), 803-809 (2004).

11. Dastjerdi, R., Montazera, M., \& Shahsavan, S. A novel technique for producing durable multifunctional textiles using nanocomposite coating. Colloids and Surfaces B: Biointerfaces 81, 32-41 (2010).

12. Scalia, S., Tursilli, R., Bianchi, A., Lo-Nostro, P., Bocci, E., Ridi, F., et al. Incorporation of the sunscreen agent, octyl methocycinnamate in a cellulosic fabric grafted with bcyclodextrin. International Journal of Pharmaceutics 308, 155-159 (2006).

13. Ibrahim, N.A., El-Zairy, E.M.R., Abdalla, W.A., \& Khalil, H.M. Combined UVprotecting and reactive printing of Cellulosic/wool blends, Carbohydrate Polymers 92, 1386- 1394 (2013).

14. Sugiyana, D., Septiani, W. Mulyawan, A.S., \& Wahyudi, T., Immobilisasi nanopartikel $\mathrm{ZnO}$ pada kain atap kapas dan evaluasi ketahanannya terhadap ultraviolet. Arena Tekstil 32 (1), 25-34 (2017).

15. Sugiyana, D., Septiani, W., Mulyawan, A.S., Wahyudi, T., Sintesis nanopartikel $\mathrm{ZnO}$ dan immobilisasinya pada kain kapas sebagai absorber ultraviolet, Arena Tekstil 32(2): 59-66 (2017).

16. Innes, B., Tsuzuki, T., Dawkins, H., Dunlop, J., Trotter, G., Nearn, M.R., et al. Nanotechnology and the cosmetic chemist. Cosmetics, aerosols and toiletries in Australia, 15 (10-12), 21-24. (2002).

17. Lu, Z., Mao, C., Meng, M., Liu, S., Tian, Y., $\mathrm{Yu}, \mathrm{L}$., et al. Fabrication of $\mathrm{CeO}_{2}$ Nanoparticlemodified Silk for UV Protection and Antibacterial Applications. Journal Colloid Interface Science 435, 8-14 (2014).

18. Kasap, S.O. Electronic materials and Devices (3rd ed.), McGraw-Hill New York (2006). 
19. Tsuzuki, T. \& Wang, X. Nanoparticle coatings for UV protective textiles, RJTA, 14 (2), 9 - 21 (2010).

20. Yadollahia, Gholamalia, I., Namazia, H., Aghazadeh, M. Synthesis and characterization of antibacterial carboxymethylcellulose/ $\mathrm{ZnO}$ nanocomposite hydrogels. International Journal of Biological Macromolecules 74, 136141 (2015). 